\title{
Serum Lipid Profiles, Relationship Between Paraoxonase/Arylesterase Activity and High-density Lipoprotein Levels in Patients with Migraine
}

\author{
Migren Hastalarında Serum Lipid Profili, Paraoksonaz/Arilesteraz Aktivitesi ve Yüksek \\ Yoğunluklu Lipoprotein Düzeyleri Arasındaki İlişki
}

\author{
Yasemin Eren1, Ebru Bilge Dirik², Salim Neşelioğlu³, Özcan Erel 3 \\ ${ }^{1}$ Health Sciences University, Diskapi Yildirim Beyazit Training and Research Hospital, Clinic of Neurology, Ankara, Turkey \\ ${ }^{2}$ Ataturk Training and Research Hospital, Clinic of Neurology, Ankara, Turkey \\ 3Yildirim Beyazit University Faculty of Medicine, Department of Biochemistry, Ankara, Turkey
}

\begin{abstract}
Objective: Paraoxonase 1 (PON1) is associated with high-density lipoprotein (HDL) and inhibits low-density lipoprotein (LDL) oxidation. The antioxidant and antiatherogenic characteristics of HDL are attributed to this feature. The mechanisms defined in the vascular atherosclerotic process, such as inflammation, oxidative stress, and endothelial dysfunction, are also present in migraine pathophysiology. The association between hyperlipidemia and migraine has been described in various studies; however, different results have been reported. We aimed to evaluate the general lipid profiles and the relationship between PON1, arylesterase (ARE) activity, and HDL levels in patients with migraine.

Materials and Methods: The study group comprised 150 patients with migraine. The control group included 71 age- and sex-matched healthy subjects. None of the subjects in either group had any vascular risk factors. PON1 and ARE activities were evaluated using a method developed by Erel. Serum lipid levels were measured using an autoanalyzer (Roche Hitachi Cobas c501).

Results: Serum lipid profiles, PON1/ARE activity and HDL levels were similar to those of the control group. No statistical correlation was found between lipid parameters and PON1 or ARE levels in the patient and control groups.

Conclusion: According to our results, investigating PON1 and ARE activities may be meaningless whenever migraineurs have no vascular risk factors. On the other hand, studies of longer duration will be required to evaluate the longitudinal relationship between PON1 and ARE activity in the etiopathogenesis of migraine.
\end{abstract}

Keywords: Paraoxonase, arylesterase, high-density lipoprotein, migraine

$\ddot{O} z$

Amaç: Paraoksonaz 1 (PON1) yüksek yoğunluklu lipoprotein (HDL) ile ilişkilidir ve düşük yoğunluklu lipoproteinin (LDL) oksidasyonunu inhibe eder. HDL'nin antioksidan ve antiaterojenik özelliği bu duruma bağlanmaktadır. Vasküler aterosklerotik süreçte tanımlanan enflamasyon, oksidatif stres ve endotelyal disfonksiyon gibi mekanizmalar migren patofizyolojisinde yer almaktadır. Çeşitli çalışmalarda hiperlipidemi migren ilişkisi tanımlanmıştır ancak farklı sonuçlar bildirilmiştir. Biz bu çalışmada migren hastalarında genel lipid profili ve PON1, ARE aktivitesi ile HDL düzeyleri arasındaki ilişkiyi incelemeyi amaçladık.

Gereç ve Yöntem: Çalışma grubuna 150 migren hastası alındı. Kontrol grubu yaş ve cinsiyet uyumlu 71 sağlıklı bireyden oluşmaktadır. Her iki gruptaki bireylerde herhangi bir vasküler risk faktörü yoktu. PON1, arilesteraz (ARE) aktiviteleri Erel tarafından geliştirilen yöntem kullanılarak değerlendirilmiştir. Serum lipid düzeyleri otoanalizör (Roche Hitachi Cobas c501) kullanılarak ölçüldü.

Address for Correspondence/Yazışma Adresi: Yasemin Eren MD, Health Sciences University, Diskapi Yildirim Beyazit Training and Research Hospital, Clinic of Neurology, Ankara, Turkey

Phone: +90 3125962000 E-mail: yeren.72@hotmail.com ORCID ID: orcid.org/0000-0001-6357-6785

Received/Geliş Tarihi: 08.09.2016 Accepted/Kabul Tarihi: 19.04.2017

${ }^{\circ}$ Copyright 2017 by Turkish Neurological Society

Turkish Journal of Neurology published by Galenos Publishing House. 


\section{Öz}

Bulgular: Serum lipid profili PON1/ARE aktivitesi ve HDL düzeyleri kontrol grubu benzerdi. Hasta ve kontrol grubunda lipid parametreleri ve PON1 ve ARE düzeyleri arasında istatiksel korelasyon bulunmadı.

Sonuç: Bizim sonuçlarımıza göre vasküler risk faktörü olmayan migrenlilerde PON1 ve ARE aktivitesini araştırmak anlamsızdır. Diğer taraftan migren etiyopatogenezinde, PON1 ve ARE aktivitesi ile longitudinal ilişkisinin değerlendirilmesi için, daha uzun süreli çalışmalara ihtiyaç vardır.

Anahtar Kelimeler: Paraoksonaz, arilesteraz, yüksek yoğunluklu lipoprotein, migren

\section{Introduction}

Although the clinical features of migraine have been well described, pathophysiology of migraine is still unclear (1). It is considered as a multifactorial neurovascular disease and various genetic, biochemical, and environmental factors play a role in its etiopathogenesis. Mechanisms such as cortical spreading depression, neurogenic inflammation, and cranial vascular contractile dysfunction, play roles in its pathophysiology (2). Migraine has been associated with systemic inflammation, oxidative stress, and thrombosis in various studies. Furthermore, vascular predisposing conditions, such as hypertension, hypercholesterolemia, increased body weight, hyperhomocysteinemia, and impaired insulin sensitivity, have been shown to be comorbidities of migraine. Migraine was even claimed to be a part of a peripheral vascular abnormality instead of being a primary cerebral phenomenon (3).

The risk of ischemic stroke and coronary heart disease are increased in migraine, particularly in migraine with aura (MWA) $(1,4)$. The interactions and associations between migraine and its comorbid disorders are not completely understood (5). The vasculature associated with migraine is probably not limited to the meningeal arteries, and it may share the same etiologic pathway with other cardiovascular diseases (6). The most probable mechanisms are endothelial dysfunction and arterial dilatation (7). The adverse vascular risk profile and inflammatory process disrupt both the vascular endothelial function and structure together, and cause atherosclerosis and vascular diseases (3).

The paraoxonase gene family (PON1, PON2 and PON3) is located on the long arm of the seventh chromosome in humans. PON1 inhibits oxidation of low-density lipoprotein (LDL) levels by inhibiting LDL oxidation, thereby preventing atherosclerosis. PON1 is located on high-density lipoprotein (HDL), and the antioxidant and antiatherogenic activities of HDL are associated with a great extent with this placement. HDL stimulates PON1 secretion from the liver and stabilizes the secreted peptide $(8,9)$. PON1 is an enzyme that has a glycoprotein structure, with both arylesterase (ARE) and paraoxonase activities. Although PON1 and PON1 ARE are two different enzymes, ARE and PON1 activity have been shown to be associated with a single gene in previous studies (10). PON1 has two common polymorphisms in the coding region [leucine $(\mathrm{L}) /$ methionine $(\mathrm{M})$ at position 55 and glutamine $(\mathrm{Q})$ /arginine $(\mathrm{R})$ at position 192] and five promoter polymorphisms (8).

The activities of PON1 and ARE found to be decreased in disorders associated with migraine, such as atherosclerotic heart disease, diabetes mellitus, ischemic stroke, and metabolic syndrome, in some studies $(9,11,12)$. The data from studies that investigated the relationship between migraine and hyperlipidemia have also been controversial. In this study, we investigated the relationship between HDL and PON1, and ARE activities, and the general lipid profile in patients with migraine, and compared these findings with a control group.

\section{Materials and Methods}

\section{Subjects}

One hundred fifty patients (121 females and 29 males; mean age, $33.96 \pm 9.40$ years) who presented to the Neurology Outpatient Clinic of the Ataturk Training and Research Hospital were prospectively included in the study. Moreover, 71 age- and sex-matched healthy control subjects (53 females and 18 males; mean age, $32.99 \pm 8.51$ years) were enrolled for comparison.

Patients diagnosed as having migraine according to the criteria of the International Headache Society (2013) were classified into two groups: those with MWA and those with migraine without aura (MWOA) (13). The frequency of episodes, pain localization, autonomic findings, pain severity, and the loss of function of patients were all evaluated. The frequency of episodes was divided into two groups, fewer than four episodes per month and more than four episodes per month. The severity of pain was evaluated using the visual analogue scale, and the loss of function was evaluated using the Migraine Disability Assessment Scale (14). The patient exclusion criteria included the presence of a systemic disease, obesity, history of malignancy, smoking, pregnancy, lactation, and the intake of medications for migraine in the previous 2 weeks.

All patients and controls were informed regarding the study details; the study was approved by the Local Ethics Committee of Ataturk Training and Research Hospital (Protocol number: 2010/99). All investigators confirmed the ethical standards as described in the Declaration of Helsinki.

\section{Methods}

\section{Blood Samples}

Blood samples were obtained after overnight fasting. Samples were collected from a cubital vein and placed into blood tubes, and the serum was separated from the cells through centrifugation at $3000 \mathrm{rpm}$ for $10 \mathrm{~min}$. Samples were stored at $-80{ }^{\circ} \mathrm{C}$ until required for analysis.

Measurement of Paraoxonase 1 and Arylesterase Enzyme Activities in Serum

PON1 and ARE activities were measured using commercially available kits (Relassay, Turkey). The fully-automated paraoxonase activity measurement method comprised two different sequential 
reagents. The first reagent was an appropriate Tris buffer, which also contained the calcium ion, a co-factor of PON1 enzyme. The second reagent was a newly developed stable substrate solution. The sample was mixed with Reagent 1 , and the substrate solution was added. The linear increase of the absorbance of p-nitrophenol, produced from paraoxon, was followed from the kinetic measurement mode. Non-enzymatic paraoxon hydrolysis was subtracted from the total hydrolysis rate. Molar absorptivity of p-nitrophenol was $18,290 \mathrm{M}^{-1} \mathrm{~cm}^{-1}$, and one unit of paraoxonase activity was equal to 1 mole of paraoxon hydrolyzed per liter per minute at $37{ }^{\circ} \mathrm{C}(15)$.

ARE activity was measured using phenylacetate PON1, which was present in the sample and hydrolyzed phenylacetate to its products of phenol and acetic acid. The produced phenol was colorimetrically measured via oxidative coupling with 4-aminoantipyrine and potassium ferricyanide. Non-enzymatic phenyl acetate hydrolysis was subtracted from the total hydrolysis rate. The molar absorptivity of the colored complex was $4000 \mathrm{M}^{-1}$ $\mathrm{cm}^{-1}$ and one unit of ARE activity was equal to 1 mole of phenyl acetate hydrolyzed per liter per minute at $37^{\circ} \mathrm{C}(16)$.

\section{Routine Parameters}

The levels of total cholesterol (TC), triglyceride (TG), HDL, and LDL were measured using an autoanalyzer (Roche Hitachi Cobas (501).

\section{Statistical Analysis}

All statistical analyses were performed using the Statistical Package for Social Sciences, version 20.0 for Windows (SSPS; Chicago, IL, USA). Data were expressed as the mean \pm standard deviation.

Student's t-test was used for dual comparisons of independent numerical variables showing normal distribution, whereas analysis of variance was used for multiple comparisons. Relationships between variables were analyzed using Pearson's or Spearman's correlation analysis according to the distribution type of the parameters. $\mathrm{P}<0.05$ was considered statistically significant.

\section{Results}

The demographic and clinical data of subjects are summarized in Table 1. There were no significant differences in the sex and ages of the patient and control groups.

We divided patients with migraine into MWA and MWOA subgroups and compared the results with each other and the control group. We observed no any significant differences in PON1, ARE, TC, TG, HDL, LDL levels between the groups (Table 2).

No statistical correlation was found between lipid parameters and paraoxonase or ARE levels in the patient and control groups.

\section{Discussion}

PON1 activity has been found to be decreased in disorders such as cardiovascular disease, diabetes mellitus, ischemic stroke,

\begin{tabular}{|c|c|c|c|}
\hline \multirow[b]{2}{*}{ Parameters } & \multicolumn{2}{|c|}{ Patients $(n=150)$} & \multirow{2}{*}{$\begin{array}{c}\text { Controls } \\
(\mathrm{n}=71)\end{array}$} \\
\hline & $\begin{array}{c}\text { MWOA } \\
(\mathrm{n}=74)\end{array}$ & $\begin{array}{l}\text { MWA } \\
(\mathrm{n}=76)\end{array}$ & \\
\hline Age (Mean \pm SD years) & $34.2 \pm 9.5$ & $33.7 \pm 9.3$ & $32.8 \pm 8.5$ \\
\hline \multicolumn{4}{|l|}{$\operatorname{Sex}(n, \%)$} \\
\hline Female & $59(79.7)$ & $62(81.6)$ & $53(74.6)$ \\
\hline Male & $15(20.3)$ & $14(18.4)$ & $18(25.4)$ \\
\hline BMI $\left(\mathrm{kg} / \mathrm{m}^{2}\right)$ & $24.2 \pm 2.6$ & $24.1 \pm 3.2$ & $24.9 \pm 3.3$ \\
\hline Family history (n, \%) & $28(37.8)$ & $41(53.9)$ & \\
\hline Nausea (n, \%) & $64(86.5)$ & $70(92.1)$ & \\
\hline Vomiting (n, \%) & $34(45.9)$ & $38(50.0)$ & \\
\hline Photophobia (n, \%) & $69(93.2)$ & $75(98.7)$ & \\
\hline Phonophobia (n, \%) & $70(94.6)$ & $72(94.7)$ & \\
\hline \multicolumn{4}{|c|}{ Frequency of attacks (n, \%) } \\
\hline Fewer than 4 per month & $26(35.1)$ & $29(38.2)$ & \\
\hline More than 4 per month & $48(64.9)$ & $47(61.8)$ & \\
\hline \multicolumn{4}{|l|}{ MIDAS score (n, \%) } \\
\hline Grade 1 & $7(9.5)$ & $10(13.2)$ & \\
\hline Grade 2 & $11(14.9)$ & $9(11.8)$ & \\
\hline Grade 3 & $18(24.3)$ & $22(28.9)$ & \\
\hline Grade 4 & $38(51.4)$ & $35(46.1)$ & \\
\hline VAS (Mean \pm SD) & $8.3 \pm 1.5$ & $8.1 \pm 1.6$ & \\
\hline
\end{tabular}

\begin{tabular}{|c|c|c|c|c|c|}
\hline Parameter $($ Mean \pm SD) & MWOA $(n=74)$ & MWA $(n=76)$ & Controls $(n=71)$ & F & $\mathrm{p}$ \\
\hline PON1 (U/L) & $225.5 \pm 110.752$ & $225 \pm 84.254$ & $231.58 \pm 97.376$ & 0.101 & 0.904 \\
\hline ARE (kU/L) & $192.93 \pm 42.99$ & $187.59 \pm 40.93$ & $190.3 \pm 35.224$ & 0.336 & 0.715 \\
\hline $\mathrm{TC}(\mathrm{mg} / \mathrm{dL})$ & $175.24 \pm 29.811$ & $170.7 \pm 40.09$ & $180.59 \pm 36.679$ & 1.402 & 0.248 \\
\hline $\mathrm{TG}(\mathrm{mg} / \mathrm{dL})$ & $130.07 \pm 87.056$ & $114.74 \pm 56.52$ & $109.61 \pm 73.395$ & 1.545 & 0.216 \\
\hline HDL-C (mg/dL) & $45.78 \pm 10.212$ & $45.79 \pm 10.69$ & $45.79 \pm 10.694$ & 0.776 & 0.462 \\
\hline LDL-C (mg/dL) & $103.75 \pm 24.669$ & $104.45 \pm 31.31$ & $111.49 \pm 29.003$ & 1.632 & 0.198 \\
\hline
\end{tabular}


and metabolic syndrome, which are all comorbidities associated with migraine $(9,11,12,17,18)$. Increased PON1 activity has been shown to be associated with a lower incidence of major cardiovascular diseases in human studies (19). Conversely, it remains unclear if this association is causal or correlational (20).

We found no differences between TC, HDL, LDL, and TG levels of the patient and control groups and also found similar PON1 and ARE activities. Yilmaz et al. (21) found higher TG levels and lower ARE activity in 62 patients with migraine when compared with a control group of 50 individuals, whereas PON1 activity and TC, HDL, and LDL levels were similar in these two groups. The lower activity of ARE was attributed to the presence of comorbidities. In the present study, the study sample was limited and co-morbid conditions such as hypertension and smoking, which interfere with both the lipid profile and paraoxonase enzyme activity were not excluded.

In the study by Yildirım et al. (22) on 104 patients with migraine and 86 healthy controls, PON1 activity and ARE were low, and the oxidized LDL and LDL levels were high. As in the study reported by Yilmaz et al. (21) the comorbid situations interfering the enzyme activity or the lipid profile are not clear in this study too. Sedentary lifestyle, smoking, alcohol use, obesity, and diet rich in fat can decrease PON1 activity (20). Furthermore, paraoxonase levels have been reported to decrease with aging (9).

PON1 activity may reveal a difference of at least 40 times in a population of humans defined according to any criteria (20). The paraoxonase gene polymorphism has an effect on enzyme concentration and activity as much as pharmacologic and environmental factors. This variability may be attributed to a genetic polymorphism at the coding (Q192R, L55) region and the promoter (T-108C) region of the PON1 gene. Alternatively, PON1 concentrations and activity were reported to be better markers of cardiovascular diseases in comparison with PON1 genotype $(8,19)$. García-Martín et al. (23) reported an absence of a difference between patients with migraine and controls in terms of PON1 genotypes and allelic variants. Yildirım et al. (22) also reported similar results.

We found similar lipid levels in patients with migraine and the control group and observed no association with the presence of aura. Gruber et al. (24) reported increased levels of TC, LDL, and oxidized LDL in patients of normal weight with migraine compared with a control group that also had normal weight, with similar levels of HDL in both groups. Moreover, Gruber et al. (24) found similar lipid profiles in patients with migraine and normal body weight in comparison with obese controls with no differences between obese patients with migraine and obese controls. Monastero et al. (25) found an association with increased plasma lipid levels, and particularly increased TC levels in patients with migraine with a mean age of 73 years. Kurth et al. (26) reported a mild association with TC, non-HDL, and apo-B100 in female patients with migraine who had a mean age of 54.7 years; these authors reported no association between the lipid profile, aura symptoms, and frequency of headache. Conversely, Scher et al. (27) found an increase in TC levels in patients with MWA. Rist et al. (28) found increased levels of TC and TG in elderly patients with MWA. These studies were retrospective and were performed with older patients. Naturally, comorbidities that were accompanied by hyperlipidemia were present. Our study was performed with patients aged 18-50 years, and conditions that may accompany hyperlipidemia such as diabetes, hypertension, obesity and smoking, were excluded. Saberi et al. (29) reported an increased frequency of hypertriglyceridemia and hypercholesterolemia in patients with migraine with a lower frequency of low HDL levels in patients with migraine.

Two different descriptions have been suggested for HDL in recent years: HDL quantity (plasma levels of circulating HDL) and HDL quality (atheroprotective properties of HDL). Although HDL concentrations have been shown to be predictive for atherosclerotic cardiovascular events in population-based largescale epidemiologic studies, it was insufficient for the evaluation of functional variations of HDL particles and the determination of the association with atherosclerotic disease risk (30). The terms 'healthy HDL', functional HDL, or 'dysfunctional HDL' have been frequently used in place of HDL in recent studies (31). The antioxidant activity of healthy HDL may be associated with potential antiatherogenic activity. Healthy HDL prevents atherosclerosis by preventing LDL oxidation via endothelial dysfunction.

Kurth (32) remarked that the different results obtained in studies that investigated vascular risk factors and atherosclerosis in patients with migraine could not be solely explained by differences in study designs or the evaluation of different patients or different migraines, and that time factors may also be important. Migraine presents with an episodic and fluctuating lifelong course, and these changes can cause difficulties in migraine classification in population-based studies. Although active migraine may not be initially associated with atherosclerosis, patients with migraine may have rapidly progressive vascular pathologies over time (32). We observed unchanged levels of HDL in patients with migraine in the present study, similar to other studies. It is possible that HDL may be dysfunctional in patients with migraine or become dysfunctional over time. PON1 was reported not to play an important role in the early pathogenesis of cardiovascular diseases in young adults in the Coronary Artery Risk Development in Young Adults study (33). When the relationship between HDL dysfunction and PON1 activity was considered, time may be an important factor in atherosclerosis development. Moreover, PON1 activity decreased with aging, which may also support this hypothesis.

\section{Conclusion}

We found similar levels of PON1 and ARE activities, HDL levels, and general lipid profiles in patients with migraine and in healthy controls. We think that our results, which are not in concordance with the results of similar studies between migraineurs and controls, may be attributed to our younger patient profile. Another reason for this discordance may be the exclusion of vascular risk factors in our groups. For this reason, we speculate that investigating PON1 and ARE activities may be meaningless whenever migraineurs have no vascular risk factors. Therefore, regular lifelong follow up of patients with migraine in respect of developing vascular risk factors may be more meaningful. We consider that larger studies are needed in this area. Antioxidants, antiplatelet agents or lipid lowering agents may have roles in migraine treatment in future, based on the current data. 


\section{Ethics}

Ethics Committee Approval: The study were approved by the Ataturk Training and Research Hospital of Local Ethics Committee (Protocol number: 2010/99).

Informed Consent: Consent form was filled out by all participants.

Peer-review: Externally peer-reviewed.

\section{Authorship Contributions}

Medical Practices: Y.E., E.B.D., Concept: Y.E., Design: Y.E., Ö.E., Data Collection or Processing: Y.E., E.B.D., S.N., Analysis or Interpretation: Y.E., Ö.E., Literature Search: Y.E., Writing: Y.E.

Conflict of Interest: The authors report no conflicts of interest.

Financial Disclosure: The authors declare that this study received no financial support.

\section{References}

1. Schürks M, Rist PM, Bigal ME, Buring JE, Lipton RB, Kurth T. Migraine and cardiovascular disease: systematic review and meta-analysis. BMJ 2009;339:b3914.

2. Silva FA, Rueda-Clausen CF, Silva SY, Zarruk JG, Guzmán JC, Morillo CA, Vesga B, Pradilla G, Flórez M, López-Jaramillo P. Endothelial function in patients with migraine during the interictal period. Headache 2007;47:4551.

3. Hamed SA. The vascular risk associations with migraine: relation to migraine susceptibility and progression. Atherosclerosis 2009;205:15-22.

4. Bigal ME, Kurth T, Santanello N, Buse D, Golden W, Robbins M, Lipton RB. Migraine and cardiovascular disease: a population-based study. Neurology 2010;74:628-635

5. Marmura MJ. Systemic abnormalities in migraine: what comes first? Neurologist 2009;15:53-54.

6. Kurth T. Migraine and ischaemic vascular events. Cephalalgia 2007;27:965975.

7. Sacco S, Ripa P, Grassi D, Pistoia F, Ornello R, Carolei A, Kurth T. Peripheral vascular dysfunction in migraine: a review. J Headache Pain 2013;14:80.

8. Aviram M, Rosenblat M. Paraoxonases and cardiovascular diseases: pharmacological and nutritional influences. Curr Opin Lipidol 2005;16:393399.

9. Gupta N, Gill K, Singh S. Paraoxonases: structure, gene polymorphism\&role in coronary artery disease. Indian J Med Res 2009;130:361-368.

10. Gan KN, Smolen A, Eckerson HW, La Du BN. Purification of human serum paraoxonase/arylesterase. Evidence for one esterase catalyzing both activities. Drug Metab Dispos 1991;19:100-106.

11. Mackness MI, Harty D, Bhatnagar D, Winocour PH, Arrol S, Ishola M, Durrington PN. Serum paraoxonase activity in familial hypercholesterolaemia and insulin-dependent diabetes mellitus. Atherosclerosis 1991;86:193-199.

12. Sentí M, Tomás M, Fitó M, Weinbrenner T, Covas MI, Sala J, Masiá R, Marrugat J. Antioxidant paraoxonase 1 activity in the metabolic syndrome. J Clin Endocrinol Metab 2003;88:5422-5426.

13. Headache Classification Subcommittee of the International Headache Society (HIS). The International Classification of Headache Disorders, 3rd edition (betaversion). Cephalalgia 2013;33:629-808.

14. Stewart WF, Lipton RB, Dowson AJ, Sawyer J. Development and testing of the Migraine Disability Assessment (MIDAS) Questionnaire to assess headache-related disability. Neurology 2001;56(Suppl 1):20-28.
15. Eckerson HW, Romson J, Wyte C, La Du BN. The human serum paraoxonase polymorphism: identification of phenotypes by their response to salts. Am J Hum Genet 1983;35:214-227.

16. Haagen L, Brock A. A new automated method for phenotyping arylesterase (EC 3.1.1.2) based upon inhibition of enzymatic hydrolysis of 4-nitrophenyl acetate by phenyl acetate. Eur J Clin Chem Clin Biochem 1992;30:391-395.

17. Ferretti G, Bacchetti T, Moroni C, Savino S, Liuzzi A, Balzola F, Bicchiega V. Paraoxonase activity in high-density lipoproteins: a comparison between healthy and obese females. J Clin Endocrinol Metab 2005;90:1728-1733.

18. Dursun P, Demirtaş E, Bayrak A, Yarali H. Decreased serum paraoxonase 1 (PON1) activity: an additional risk factor for atherosclerotic heart disease in patients with PCOS? Hum Reprod 2006;21:104-108.

19. Bhattacharyya T, Nicholls SJ, Topol EJ, Zhang R, Yang X, Schmitt D, Fu X, Shao M, Brennan DM, Ellis SG, Brennan ML, Allayee H, Lusis AJ, Hazen SL. Relationship of paraoxonase 1 (PON1) gene polymorphisms and functional activity with systemic oxidative stress and cardiovascular risk. JAMA 2008;299:1265-1276.

20. Eren E, Yilmaz N, Aydin O. Functionally defective high-density lipoprotein and paraoxonase: a couple for endothelial dysfunction in atherosclerosis. Cholesterol 2013;2013:792090.

21. Yilmaz N, Aydin O, Yegin A, Tiltak A, Eren E. Increased levels of total oxidant status and decreased activity of arylesterase in migraineurs. Clin Biochem 2011;44:832-837.

22. Yıldırım S, Akar S, Kuyucu M, Yıldırım A, Dane S, Aygül R. Paraoxonase 1 gene polymorphisms, paraoxonase/arylesterase activities and oxidized lowdensity lipoprotein levels in patients with migraine. Cell Biochem Funct 2011;29:549-554.

23. García-Martín E, Martínez C, Serrador M, Alonso-Navarro H, Navacerrada F, Agúndez JA, Jiménez-Jiménez FJ. Paraoxonase 1 (PON1) polymorphisms and risk for migraine. J Neurol 2010;257:1482-1485.

24. Gruber HJ, Bernecker C, Pailer S, Lechner A, Horejsi R, Möller R, Fazekas F, Truschnig-Wilders M. Lipid profile in normal weight migraineurs - evidence for cardiovascular risk. Eur J Neurol 2010;17:419-425.

25. Monastero R, Pipia C, Cefalù AB, Liveri ET, Rosano R, Camarda R, Camarda C. Association between plasma lipid levels and migraine in subjects aged $>$ or $=50$ years: preliminary data from the Zabùt Aging Project. Neurol Sci 2008;29(Suppl 1):179-181.

26. Kurth T, Schürks M, Logroscino G, Gaziano JM, Buring JE. Migraine, vascular risk, and cardiovascular events in women: prospective cohort study BMJ 2008;337:a636.

27. Scher AI, Terwindt GM, Picavet HS, Verschuren WM, Ferrari MD, Launer LJ. Cardiovascular risk factors and migraine: the GEM population-based study. Neurology 2005;64:614-620.

28. Rist PM, Tzourio C, Kurth T. Associations between lipid levels and migraine: cross-sectional analysis in the epidemiology of vascular ageing study. Cephalalgia 2011;31:1459-1465.

29. Saberi A, Hatamian HR, Kazemnejad E, Ghorbannejad N. Hyperlipidemia in migraine: Is it more frequent in migraineurs? Iran J Neurol 2011;10:4650.

30. Gordon SM, Hofmann S, Askew DS, Davidson WS. High density lipoprotein: it's not just about lipid transport anymore. Trends Endocrinol Metab 2011;22:9-15.

31. Mineo C, Deguchi H, Griffin JH, Shaul PW. Endothelial and antithrombotic actions of HDL. Circ Res 2006;98:1352-1364.

32. Kurth T. Migraine a marker of vascular health? Cephalalgia 2013;33:226227.

33. Thyagarajan B, Jacobs DR Jr, Carr JJ, Alozie O, Steffes MW, Kailash P, Hayes $\mathrm{JH}, \mathrm{Gross} \mathrm{MD}$. Factors associated with paraoxonase genotypes and activity in a diverse, young, healthy population: the Coronary Artery Risk Development in Young Adults (CARDIA) study. Clin Chem 2008;54:738-746. 